\title{
Yeast culture supplementation prevented milk fat depression by a short-term dietary challenge with fermentable starch
}

\author{
R. A. Longuski, Y. Ying, and M. S. Allen ${ }^{1}$ \\ Department of Animal Science, Michigan State University, East Lansing 48824
}

\begin{abstract}
Effects of yeast culture on responses to a fermentable starch challenge were evaluated in an experiment with a crossover arrangement of treatments for yeast culture supplementation with 28 -d periods and a fermentable starch challenge on the last $2 \mathrm{~d}$ of each 28 -d period as a split plot within period. Eight ruminally cannulated, midlactation, multiparous Holstein cows $(96 \pm 14 \mathrm{~d}$ in milk) were randomly assigned to treatment sequence. Treatments were yeast culture or control (mix of dry ground corn and soybean meal), top-dressed at $56 \mathrm{~g}$ per head per day throughout each period. Diets containing dry ground corn grain were fed from d 1 through 26 of each period. On the last $2 \mathrm{~d}$ of each period, the dry ground corn was replaced by finely ground highmoisture corn grain on an equivalent dry matter basis to abruptly increase ruminal fermentability of dietary starch. Response variables were averaged for d 25 and 26 for the dry corn treatment and for d 27 and 28 for the high-moisture corn treatment each period. The fermentable starch challenge decreased dry matter intake by $1.9 \mathrm{~kg} / \mathrm{d}$ and tended to increase milk yield compared with the dry corn diet. However, effects of the fermentable starch challenge on yield of milk fat varied for the yeast culture and control diets; yield of milk fat decreased from 1.42 to $1.30 \mathrm{~kg} / \mathrm{d}$ for the control treatment but increased from 1.40 to $1.47 \mathrm{~kg} / \mathrm{d}$ for the yeast culture treatment. Milk fat concentration tended to decrease from 3.34 to $3.03 \%$ during the dietary challenge compared with the base diet for the control treatment but was not affected (mean $=3.32 \%$ ) by the dietary challenge for the yeast culture treatment. An interaction of treatments was also detected for fatcorrected milk, which increased from 41.0 to $43.0 \mathrm{~kg} / \mathrm{d}$ for the yeast culture treatment but decreased from 41.6 to $39.8 \mathrm{~kg} / \mathrm{d}$ for the control diet with the fermentable starch challenge. Frequency of ruminating bouts was decreased by yeast culture compared with control (12.8 vs. 15.7 bouts/d) but not the fermentable starch chal-
\end{abstract}

Received January 2, 2008.

Accepted September 2, 2008.

${ }^{1}$ Corresponding author: allenm@msu.edu lenge. No treatment interactions were observed for any measure of ruminal $\mathrm{pH}$, total or individual volatile fatty acid concentration in ruminal fluid, acetate:propionate ratio, or individual fatty acid isomers in milk fat. Yeast culture supplementation may help prevent depression in milk fat during transition to a diet with highly fermentable starch, but the mechanism responsible remains to be elucidated.

Key words: rumination, high-moisture corn, diet fermentability

\section{INTRODUCTION}

Highly fermentable diets can decrease meal size and feed intake (Oba and Allen, 2003), fiber digestibility (Hoover, 1986), and increase flow of trans fatty acids (FA) from the rumen resulting in milk fat depression (Bradford and Allen, 2004). Increased ruminal starch fermentation can result in increased partitioning of energy to body condition at the expense of milk yield (Oba and Allen, 2000). Stabilization of ruminal fermentation has been suggested as a benefit of yeast culture (YC) supplementation (Williams et al., 1991). Saccharomyces cerevisiae culture stimulated growth of lactate-utilizing and cellulolytic microbes in vitro (Callaway and Martin, 1997), and increasing populations of lactate-utilizing microbes might attenuate transient lactate spikes during diet shifts in vivo (Miller-Webster et al., 2002). Williams et al. (1991) observed an overall decrease in ruminal concentrations of lactic acid in steers fed $\mathrm{YC}$ and a reduction in ruminal $\mathrm{pH}$ depression $2 \mathrm{~h}$ after feeding barley grain. However, effects of $\mathrm{YC}$ on ruminal $\mathrm{pH}$ have been inconsistent. Although YC decreased peak ruminal lactic acid concentration in lactating cows, no difference was observed for ruminal $\mathrm{pH}$ (Erasmus et al., 1992). Others have shown YC to lower ruminal pH (Harrison et al., 1988; Piva et al., 1993) or have no effect on ruminal pH (Wiedmeier et al., 1987; Yoon and Stern, 1996; Robinson and Garrett, 1999). Differences in ruminal $\mathrm{pH}$ have also been reported between different $\mathrm{YC}$ sources in vitro in continuous culture (Miller-Webster et al., 2002).

Variation in diet fermentability is a regular occurrence on commercial dairy farms because of changes in 
moisture concentration and composition of ingredients, mixing errors, sorting of feeds by animals, and other factors (Stone, 2004). This variation can impair animal health and result in decreased milk yield and efficiency of milk production. Supplementation of YC can potentially improve milk yield and efficiency of conversion of feed to milk by altering populations of microbes in the rumen.

The objective of this experiment was to assess the effects of YC supplementation on ruminal fermentation and production responses to a fermentable starch challenge in lactating dairy cows. We hypothesized that YC treatment would attenuate the decrease in ruminal $\mathrm{pH}$ and milk fat yield from a fermentable starch challenge.

\section{MATERIALS AND METHODS}

\section{Design and Treatments}

Eight ruminally cannulated, midlactation multiparous Holstein cows $(96 \pm 14$ DIM; mean $\pm \mathrm{SD})$ from the Michigan State University Dairy Cattle Teaching and Research Center were assigned randomly to treatment sequence in a crossover design experiment with 28-d periods. Experimental procedures were approved by the Institutional Animal Care and Use Committee at Michigan State University before the start of this study. Treatments were YC (Diamond V XP, Diamond V Mills, Cedar Rapids, IA) or control (CONT) containing a mix of dry, finely ground shelled corn and soybean meal ( $48 \% \mathrm{CP})$ formulated to be isonitrogenous to $\mathrm{YC}$ and top-dressed at $56 \mathrm{~g} /$ head daily throughout each period. A fermentable starch challenge was administered as a split plot within each period. Diets containing the dry corn treatment (DC) were fed from d 1 through 26 of each period followed by the fermentable starch challenge, in which dry ground corn was replaced with the high-moisture corn treatment (HMC) on an equivalent DM basis for the final $2 \mathrm{~d}$ of each period (d 27 to 28). At the beginning of the experiment, BW of cows was $620 \pm 45 \mathrm{~kg}$ and milk yield was $45 \pm 5.5 \mathrm{~kg} / \mathrm{d}$ (mean $\pm \mathrm{SD}$ ). Samples and data were collected the last $4 \mathrm{~d}$ of each period corresponding to the last $2 \mathrm{~d}$ of the DC treatment and the $2 \mathrm{~d}$ of the dietary challenge (HMC). Diets contained corn silage ( $67 \%$ of forage DM), alfalfa silage (33\% of forage DM), corn grain (DC or HMC), expeller soybean meal (SoyPlus, West Central Soy, Ralston, IA), soybean meal (48\% CP), distillers grains, a premix of minerals and vitamins, and $\mathrm{YC}$ or CONT treatments (Table 1). The diets containing DC treatment were intended to be highly fermentable to ensure detection of treatment effects during the fermentable starch challenge. Therefore, diets were formulated for the minimum concentration of NDF suggested by NRC
Table 1. Ingredients and nutrient composition of experimental $\operatorname{diets}^{1}$

\begin{tabular}{|c|c|c|}
\hline Item & $\mathrm{DC}$ & $\mathrm{HMC}$ \\
\hline \multicolumn{3}{|l|}{ Diet ingredient, $\%$ of $\mathrm{DM}$} \\
\hline Distillers grains & 6.0 & 6.0 \\
\hline Soybean meal (48\% CP) & 8.2 & 8.2 \\
\hline Dry ground shelled corn & 36.2 & - \\
\hline High-moisture corn & - & 36.2 \\
\hline Alfalfa silage & 11.8 & 11.8 \\
\hline Corn silage & 23.5 & 23.5 \\
\hline SoyPlus ${ }^{2}$ & 4.6 & 4.6 \\
\hline Mineral and vitamin $\operatorname{mix}^{3}$ & 9.8 & 9.8 \\
\hline \multicolumn{3}{|l|}{ Nutrient composition, ${ }^{4} \%$} \\
\hline $\mathrm{DM}$ & 53.6 & 52.3 \\
\hline Starch & 33.2 & 35.1 \\
\hline $\mathrm{NDF}$ & 24.6 & 23.9 \\
\hline $\mathrm{CP}$ & 16.5 & 16.3 \\
\hline \multicolumn{3}{|c|}{$\begin{array}{l}{ }^{1} \mathrm{DC}=\text { dry ground corn grain treatment }(\mathrm{d} 1 \text { to } 26 \text { of each period } \\
\mathrm{HMC}=\text { high-moisture corn grain treatment (d } 27 \text { to } 28 \text { of each p } \\
\text { riod). }\end{array}$} \\
\hline \multicolumn{3}{|c|}{${ }^{2}$ SoyPlus (West Central Soy, Ralston, IA). } \\
\hline \multicolumn{3}{|c|}{$\begin{array}{l}{ }^{3} \text { Mineral and vitamin mix contained } 67.8 \% \text { dry ground shelled corn, } \\
13.1 \% \text { limestone, } 8.5 \% \text { magnesium sulfate, } 6.4 \% \text { white salt, } 2.9 \% \text { di- } \\
\text { calcium phosphate, } 1.3 \% \text { trace minerals, and vitamin A, D, and E } \\
\text { premix. }\end{array}$} \\
\hline
\end{tabular}

(2001). Diets were formulated to $25 \% \mathrm{NDF}$ and $17 \%$ $\mathrm{CP}$, and mineral and vitamins were formulated according to NRC (2001) recommendations. Dry matter concentration was determined twice weekly for forages, and diets were adjusted when necessary.

\section{Data and Sample Collection}

Throughout the experiment, cows were housed in individual tie stalls. Access to feed was blocked between 1000 and $1130 \mathrm{~h}$, and orts and feed offered were weighed and recorded for each cow during each collection period. Cows were fed to $110 \%$ of expected intake. Water was available ad libitum in each stall. Stalls were bedded with sawdust and cleaned twice daily. Dry matter intake was recorded for each cow daily. Samples of diet ingredients $(0.5 \mathrm{~kg})$ and orts $(12.5 \%)$ were collected on d 25 to 28 of each period. Diet ingredients and ort samples for individual cows were composited (d 25 and 26 for the DC treatment diet and d 27 and 28 for the HMC treatment diet). Cows were milked twice daily at 0500 and $1700 \mathrm{~h}$, and milk was sampled at each milking from d 25 to 28 of each period. Cows were milked in a milking parlor on d 1 to 24 of each period and were milked in their tie stalls on d 25 to 28 of each period. Two samples were taken from each cow at each milking; one sample was immediately frozen for later determination of FA profiles and the other was collected in a sealable tube containing a preservative and refrigerated for later determination of milk composition. Body weights were measured immediately before the experiment and 
on d 28 of each period. Body condition was scored by 3 trained investigators on a 5 -point scale where $1=$ thin and 5 fat, as described by Wildman et al. (1982), immediately before the experiment and on d 28 of each period for each animal. Feeding and chewing behavior and ruminal $\mathrm{pH}$ were continuously monitored (every 5 s) on d 25 to 28 of each period using a computerized data acquisition system (Dado and Allen, 1993). From d 25 to 28 of each period, $\mathrm{pH}$ probes were removed at $1000 \mathrm{~h}$ to check calibration and were recalibrated if necessary. Daily mean, minimum, maximum, variation range, and hours below pH 6.0 unweighted or weighted by the deviation in $\mathrm{pH}$ units were calculated. Response variables were averaged for d 25 and 26 for the DC treatment and for d 27 and 28 for HMC treatment each period. Rumen fluid was sampled every $3 \mathrm{~h}$ with an indwelling sampling device weighted in the ventral rumen on d 26 and 27 of each period and analyzed for short-chain FA and ammonia.

\section{Sample and Statistical Analysis}

Diet ingredients and orts were dried in a $55^{\circ} \mathrm{C}$ forcedair oven for $72 \mathrm{~h}$ and analyzed for DM concentration. All samples were ground with a Wiley mill (1-mm screen; Arthur H. Thomas, Philadelphia, PA). Samples were analyzed for NDF, CP, and starch. Concentrations of NDF were determined according to Van Soest et al. (1991, method A), and CP was analyzed according to Hach et al. (1987). Starch was measured by an enzymatic method (Karkalas, 1985) after samples were gelatinized with sodium hydroxide; glucose concentration was measured with a glucose oxidase method (Sigma Chemical Co., St. Louis, MO).

Milk samples were analyzed for fat, true protein, and lactose by midinfrared spectroscopy (AOAC, 1990) by Universal Labs (East Lansing, MI). Milk samples were composited across d 25 and 26 and across d 27 and 28 of each period for determination of FA profile so that equal amounts of milk fat were contributed from each sample composited. Composite samples were centrifuged at $17,800 \times \mathrm{g}$ for $30 \mathrm{~min}$ at $8^{\circ} \mathrm{C}$, and approximately $350 \mathrm{mg}$ of fat cake was extracted according to Hara and Radin (1978). Methyl esters were formed according to Christie (1982) as modified by Chouinard et al. (1999). Fatty acids were quantified by gas chromatography (Clarus 500, Perkin-Elmer Corp., Norwalk, CT) according to Kramer et al. (1997) using a SP-2560 capillary column $(100 \mathrm{~m} \times 0.20 \mathrm{~mm}$ i.d. with $0.02-\mu \mathrm{m}$ film thickness; Supelco, Bellefonte, PA). Oven temperature was $70^{\circ} \mathrm{C}$ for $4 \mathrm{~min}$ then increased $13^{\circ} \mathrm{C} / \mathrm{min}$ to $175^{\circ} \mathrm{C}$ and was held for $27 \mathrm{~min}$ before being increased again at $4^{\circ} \mathrm{C} /$ min to $215^{\circ} \mathrm{C}$ and held for $31 \mathrm{~min}$. Helium was used as the carrier gas, and the total run time was $80 \mathrm{~min}$.
Each sample was run at 2 split modes (1:20 and 1:100) to quantify low- and high-abundance FA, respectively. Rumen fluid was analyzed for concentration of major VFA and lactate by HPLC (Waters Corp., Milford, MA) according to Oba and Allen (2003). Ammonia concentration was determined for centrifuged rumen fluid samples according to Broderick and Kang (1980).

Data were statistically analyzed using the MIXED procedure of SAS (version 9.1.3) according to the following model:

$$
\begin{aligned}
\mathrm{Y}_{\mathrm{ijkl}}= & \mu+\mathrm{C}_{\mathrm{i}}+\mathrm{P}_{\mathrm{j}}+\mathrm{T}_{\mathrm{k}}+\mathrm{CPT}_{\mathrm{ijk}} \\
& +\mathrm{D}_{\mathrm{l}}+\mathrm{TD}_{\mathrm{kl}}+\mathrm{e}_{\mathrm{ijkl}}
\end{aligned}
$$

where $\mu=$ overall mean; $\mathrm{C}_{\mathrm{i}}=$ random effect of cow (i $=1$ to 8$) ; P_{j}=$ fixed effect of period $(\mathrm{j}=1$ to 2$) ; \mathrm{T}_{\mathrm{k}}=$ fixed effect of $\mathrm{YC}(\mathrm{k}=1$ to 2$)$; $\mathrm{CPT}_{\mathrm{ijk}}=$ interaction of cow, period, and $\mathrm{YC} ; \mathrm{D}_{1}=$ fixed effect of fermentable starch challenge $(1=1$ to 2$)$; $\mathrm{TD}_{\mathrm{kl}}=$ interaction of $\mathrm{YC}$ and fermentable starch challenge; and $\mathrm{e}_{\mathrm{ijkl}}=$ residual.

Main effects of YC treatment were tested with the mean square error for the interaction of cow, period, and $\mathrm{YC}$, and main effect of the fermentable starch challenge and its interaction with $\mathrm{YC}$ were tested using residual mean square error. Treatment effects were declared significant at $P \leq 0.05$ and tendencies for treatment effects at $P \leq 0.10$. Interactions were declared significant at $P \leq 0.10$ and tendencies for interactions at $P \leq 0.15$. When interactions among main effects were significant, treatment means were separated using Tukey's Honestly Significant Difference test (SAS version 9.1.3, SAS Institute Inc., Cary, NC).

\section{RESULTS}

Significant interactions of treatments were detected for yields of milk fat and 3.5\% FCM $(P<0.01$; Table 2 ). Increased starch fermentability (HMC compared with DC) increased milk fat yield (1.40 to $1.47 \mathrm{~kg} / \mathrm{d}$ ) for YC but decreased it (1.42 to $1.30 \mathrm{~kg} / \mathrm{d})$ for CONT. Milk yield tended to increase $(P=0.07)$ for HMC compared with DC. Milk fat concentration was not affected by the fermentable starch challenge for YC but tended to decrease for CONT (3.34 to $3.03 \%$; interaction $P=$ $0.11)$. Increased starch fermentability increased yield of $3.5 \%$ FCM from 41.0 to $43.0 \mathrm{~kg} / \mathrm{d}$ for YC but decreased it from 41.6 to $39.8 \mathrm{~kg} / \mathrm{d}$ for CONT (interaction $P<$ 0.01). The HMC treatment decreased concentrations of milk protein $(2.99$ vs. $2.93 \%, P<0.01)$ and SNF (8.83 vs. $8.72, P<0.01)$ compared with DC, but yields of milk protein, lactose, and SNF were not affected by treatment. 
Table 2. Milk production response to yeast culture (YC) and starch fermentability treatments ${ }^{1}$

\begin{tabular}{|c|c|c|c|c|c|c|c|c|}
\hline Item & \multicolumn{2}{|c|}{ Control } & \multicolumn{2}{|c|}{$\mathrm{YC}$} & SEM & \multicolumn{3}{|c|}{$P$-value } \\
\hline \multicolumn{9}{|l|}{ Yield, $\mathrm{kg} / \mathrm{d}$} \\
\hline FCM $(3.5 \%)$ & 41.6 & 39.8 & 41.0 & 43.0 & 1.3 & 0.80 & 0.32 & 0.004 \\
\hline Milk fat & 1.42 & 1.30 & 1.40 & 1.47 & 0.06 & 0.47 & 0.20 & 0.006 \\
\hline Milk protein & 1.28 & 1.27 & 1.27 & 1.31 & 0.04 & 0.51 & 0.51 & 0.19 \\
\hline Fat & 3.34 & 3.03 & 3.32 & 3.31 & 0.21 & 0.09 & 0.17 & 0.11 \\
\hline Protein & 2.99 & 2.92 & 2.99 & 2.94 & 0.06 & 0.005 & 0.79 & 0.46 \\
\hline Lactose & 5.16 & 5.13 & 5.13 & 5.10 & 0.06 & 0.22 & 0.25 & 0.88 \\
\hline SNF & 8.84 & 8.73 & 8.81 & 8.71 & 0.14 & 0.006 & 0.40 & 0.77 \\
\hline DMI, $\mathrm{kg} / \mathrm{d}$ & 27.5 & 25.4 & 27.7 & 26.0 & 1.11 & 0.006 & 0.71 & 0.76 \\
\hline $3.5 \% \mathrm{FCM} / \mathrm{DMI}$ & 1.55 & 1.60 & 1.50 & 1.67 & 0.06 & 0.02 & 0.91 & 0.15 \\
\hline
\end{tabular}

${ }^{1} \mathrm{FS}=$ main effect of fermentable starch challenge $(\mathrm{DC}=$ dry ground corn grain treatment, $\mathrm{d} 1$ to 26 ; HMC = high-moisture corn grain treatment, d 27 to 28$) ; \mathrm{YC}=$ main effect of yeast culture; $\mathrm{FS} \times \mathrm{YC}=$ interaction of dietary challenge and yeast culture.

${ }^{2}$ Main effect of conservation method was not measured.

Dry matter intake decreased $1.9 \mathrm{~kg} / \mathrm{d}$ by HMC compared with DC $(P=0.02$, Table 2$)$ because of decreased meal frequency $(9.9$ vs. 8.4 meals $/ \mathrm{d}, P=0.03$, Table $3)$. The reduction in DMI for HMC compared with DC with no effect on 3.5\% FCM resulted in increased efficiency of milk production as determined by $3.5 \%$ FCM/DMI (1.53 vs. $1.64, \mathrm{~kg} / \mathrm{kg} ; P=0.02$, Table 2 ). Number of ruminating bouts per day decreased by YC compared with CONT (15.7 vs. $12.8, P=0.04$, Table $3)$. This resulted in numerical but not significant $(P=$ 0.13 ) decreases in total ruminating time and number of ruminating chews per day. Water intake and drinking behavior were not affected by treatment.

The HMC treatment increased ruminal VFA concentrations compared with DC (117.4 vs. $111.5 \mathrm{mM}, P$ $=0.03$ ) mainly from increased butyrate concentration

Table 3. Feeding behavior response to yeast culture (YC) and starch fermentability treatments

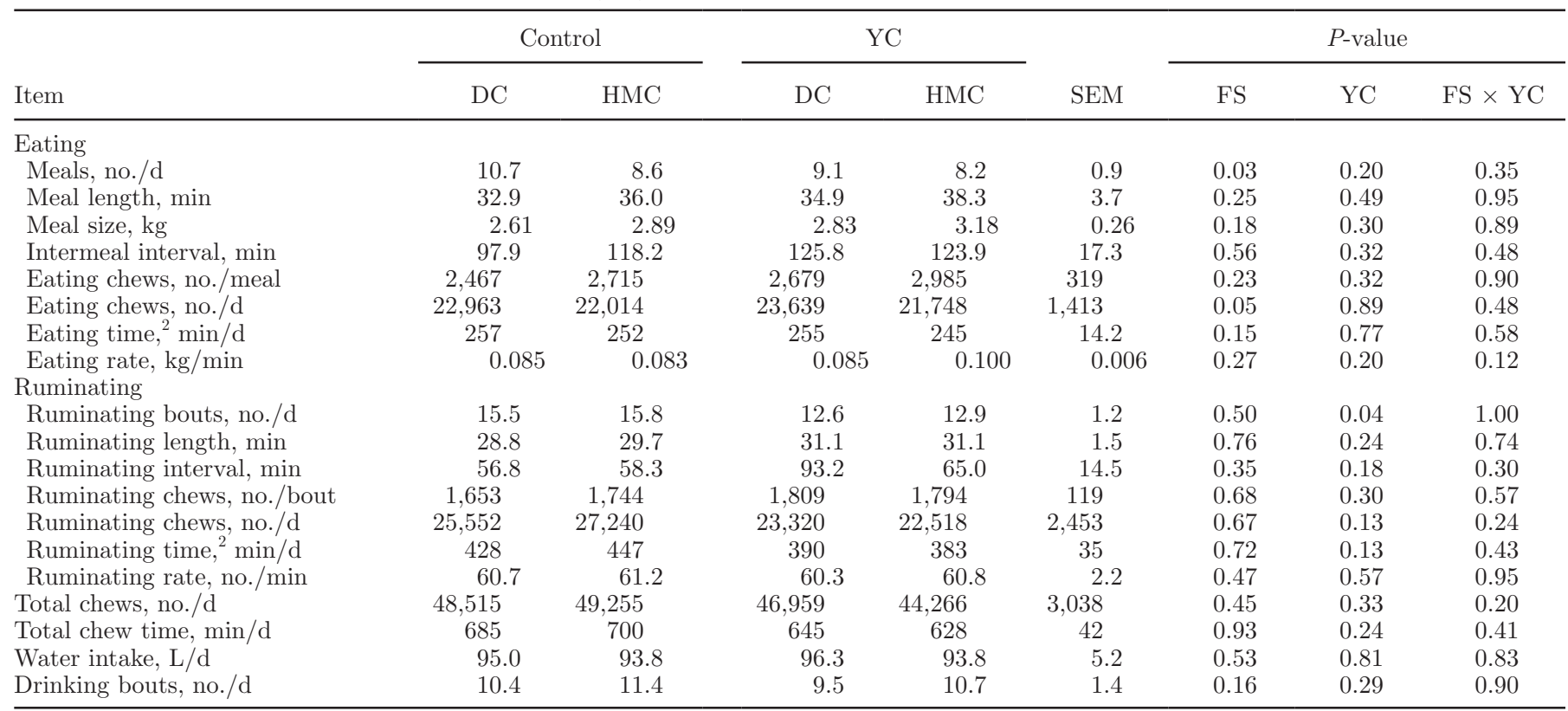

${ }^{1} \mathrm{FS}=$ main effect of fermentable starch challenge $(\mathrm{DC}=$ dry ground corn grain treatment, $\mathrm{d} 1$ to 26 ; HMC = high-moisture corn grain treatment, d 27 to 28); YC = main effect of yeast culture; FS $\times$ YC = interaction of dietary challenge and yeast culture.

${ }^{2}$ Actual time spent chewing (not a product of number of bouts and bout length). 
Table 4. Ruminal VFA, lactate, and ammonia concentration response to yeast culture (YC) and starch fermentability treatments ${ }^{1}$

\begin{tabular}{|c|c|c|c|c|c|c|c|c|}
\hline Item & \multicolumn{2}{|c|}{ Control } & \multicolumn{2}{|c|}{$\mathrm{YC}$} & SEM & \multicolumn{3}{|c|}{$P$-value } \\
\hline Total VFA, $\mathrm{m} M$ & 110.7 & 115.5 & 112.2 & 119.3 & 3.2 & 0.03 & 0.51 & 0.64 \\
\hline Propionate & 26.1 & 28.5 & 25.5 & 27.6 & 1.95 & 0.06 & 0.66 & 0.86 \\
\hline Butyrate & 13.9 & 15.1 & 15.1 & 18.6 & 1.49 & 0.02 & 0.28 & 0.18 \\
\hline Isobutyrate & 1.10 & 1.13 & 1.19 & 1.29 & 0.08 & 0.30 & 0.18 & 0.54 \\
\hline Acetate:propionate & 2.59 & 2.54 & 2.66 & 2.61 & 0.20 & 0.60 & 0.67 & 1.00 \\
\hline Lactate, $\mathrm{m} M$ & 0.35 & 0.48 & 0.36 & 0.25 & 0.11 & 0.87 & 0.30 & 0.20 \\
\hline Ammonia, mg/dL & 7.11 & 6.42 & 8.07 & 7.42 & 0.49 & 0.01 & 0.13 & 0.93 \\
\hline
\end{tabular}

${ }^{1} \mathrm{FS}=$ main effect of fermentable starch challenge $(\mathrm{DC}=$ dry ground corn grain treatment, $\mathrm{d} 1$ to 26 ; HMC = high-moisture corn grain treatment, $\mathrm{d} 27$ to 28$) ; \mathrm{YC}=$ main effect of yeast culture; $\mathrm{FS} \times \mathrm{YC}=$ interaction of dietary challenge and yeast culture.

(16.9 vs. $14.5 \mathrm{~m} M, P=0.02)$ and a tendency for increased propionate concentration (29.0 vs. $25.8 \mathrm{mM}$, $P=0.06)$. Ruminal ammonia concentration was decreased by HMC compared with DC (7.59 vs. $6.92 \mathrm{mg} /$ $\mathrm{dL}, P=0.01)$, whereas concentration of lactate was low $(<0.5 \mathrm{~m} M)$ and not affected by treatment (Table 4$)$. No main effects of YC or interactions of treatments on concentrations of VFA, lactate or ammonia, or ratio of acetate to propionate were detected.

The HMC treatment decreased mean ruminal $\mathrm{pH}$ from 6.04 to $5.91(P<0.01$, Table 5$)$ and increased fraction of time less than $\mathrm{pH} 6.0$ from 9.1 to $11.8 \mathrm{~h} / \mathrm{d}$ $(P=0.03)$ compared with DC. Time under $\mathrm{pH} 6.0$, weighted by the deviation in $\mathrm{pH}$ units, increased from 327 to 533 unit hours $(P=0.01)$ for HMC compared with DC. The HMC treatment also tended to decrease minimum (5.41 vs. 5.31, $P=0.08)$ and maximum (6.61 vs. $6.56, P=0.09$ ) daily ruminal $\mathrm{pH}$. No main effects of $\mathrm{YC}$ or interactions of treatments were observed for any measure of ruminal $\mathrm{pH}$.

Most milk FA were unaffected by treatment (individual FA data not shown). No effect of treatment was observed for FA less than $\mathrm{C} 16$ as a percentage of total milk FA, but C16:0 increased (28.4 vs. $27.7 \%, P$
$<0.01$ ) and total C18 FA tended to decrease (37.8 vs. $38.9 \%, P=0.10$, Table 6 ) for HMC compared with DC. No effect of treatment was observed for total cis $\mathrm{C} 18: 1$ FA $(21.4 \%)$, trans $18: 1$ FA $(2.22 \%)$, or trans-10, cis-12 conjugated linoleic acid (CLA; 0.01\%).

\section{DISCUSSION}

Effects of YC on yields of milk and milk fat have been inconsistent. Although no previous experiments that we know of have evaluated effects of YC on milk production response to a fermentable starch challenge, others have detected an interaction between YC supplementation and diet fermentability. A previous experiment with a similar feeding rate $(60 \mathrm{~g} / \mathrm{d})$ of the same $\mathrm{YC}$ product used in our experiment detected a significant interaction between YC and diet forage NDF concentration (Wang et al., 2001). Yeast culture treatment increased yields of milk fat and $3.5 \%$ FCM for the $21 \%$ forage NDF diet but not for the $17 \%$ NDF diet (interactions: $P=0.12$ of milk fat yield and $P=0.10$ for $3.5 \% \mathrm{FCM}$ yield). Although decreased forage NDF concentration is often associated with increased diet fermentability, the reverse is more likely in this instance. The $17 \%$

Table 5. Ruminal $\mathrm{pH}$ response to yeast culture $(\mathrm{YC})$ and starch fermentability treatments ${ }^{1}$

\begin{tabular}{|c|c|c|c|c|c|c|c|c|}
\hline \multirow[b]{2}{*}{ Item } & \multicolumn{2}{|c|}{ Control } & \multicolumn{2}{|c|}{$\mathrm{YC}$} & \multirow[b]{2}{*}{ SEM } & \multicolumn{3}{|c|}{$P$-value } \\
\hline & $\mathrm{DC}$ & $\mathrm{HMC}$ & $\mathrm{DC}$ & HMC & & $\mathrm{FS}$ & $\mathrm{YC}$ & $\mathrm{FS} \times \mathrm{YC}$ \\
\hline Mean & 6.04 & 5.90 & 6.04 & 5.91 & 0.07 & 0.003 & 0.95 & 0.83 \\
\hline Variance & 0.13 & 0.14 & 0.11 & 0.13 & 0.02 & 0.34 & 0.51 & 0.48 \\
\hline Range & 1.24 & 1.22 & 1.14 & 1.27 & 0.09 & 0.35 & 0.77 & 0.22 \\
\hline Minimum & 5.37 & 5.31 & 5.45 & 5.31 & 0.08 & 0.07 & 0.58 & 0.48 \\
\hline Maximum & 6.62 & 6.53 & 6.60 & 6.58 & 0.07 & 0.09 & 0.84 & 0.25 \\
\hline Time $<6.0, \mathrm{~h} / \mathrm{d}$ & 8.84 & 12.01 & 9.37 & 11.52 & 1.81 & 0.03 & 0.99 & 0.64 \\
\hline Area $<6.0$, unit $\mathrm{h}$ & 339 & 557 & 314 & 509 & 119 & 0.01 & 0.78 & 0.88 \\
\hline
\end{tabular}

${ }^{1} \mathrm{FS}=$ main effect of fermentable starch challenge $(\mathrm{DC}=$ dry ground corn grain treatment, $\mathrm{d} 1$ to 26 ; HMC $=$ high-moisture corn grain treatment, d 27 to 28); YC = main effect of yeast culture; FS $\times$ YC $=$ interaction of dietary challenge and yeast culture. 
Table 6. Milk fatty acid profile (\% of total fatty acids) response to yeast culture (YC) and starch fermentability treatments ${ }^{1}$

\begin{tabular}{|c|c|c|c|c|c|c|c|c|}
\hline Item & \multicolumn{2}{|c|}{ Control } & \multicolumn{2}{|c|}{$\mathrm{YC}$} & SEM & \multicolumn{3}{|c|}{$P$-value } \\
\hline \multicolumn{9}{|l|}{ Fatty acid, $\%$ of total } \\
\hline C16:0 & 27.66 & 28.08 & 27.80 & 28.78 & 0.60 & 0.004 & 0.33 & 0.19 \\
\hline Total C18 & 39.15 & 38.55 & 38.64 & 37.11 & 1.15 & 0.10 & 0.21 & 0.46 \\
\hline C18:1 trans & 2.14 & 2.28 & 2.29 & 2.18 & 0.29 & 0.88 & 0.80 & 0.19 \\
\hline $\begin{array}{l}\text { Conjugated linoleic acid } \\
\text { (trans-10, cis-12) }\end{array}$ & 0.016 & 0.008 & 0.008 & 0.008 & 0.005 & 0.27 & 0.41 & 0.37 \\
\hline
\end{tabular}

${ }^{1} \mathrm{FS}=$ main effect of fermentable starch challenge $(\mathrm{DC}=$ dry ground corn grain treatment, $\mathrm{d} 1$ to 26 ; HMC $=$ high-moisture corn grain treatment, d 27 to 28); YC = main effect of yeast culture; FS $\times$ YC $=$ interaction of dietary challenge and yeast culture.

${ }^{2}$ Includes C18:0 plus C18:1, C18:2, and C18:3 isomers.

forage NDF diet had lower concentrations of corn grain and corn silage and a much greater concentration of soyhulls, which decreased the NSC concentration of the diet from 37.9 to $32.8 \%$. Therefore, the $21 \%$ forage NDF diet was likely more fermentable than the $17 \%$ forage NDF diet, and treatment effects are consistent with those in our experiment.

Williams et al. (1991) reported that $10 \mathrm{~g} / \mathrm{d}$ of live yeast plus growth medium (Saccharomyces cerevisiae; YEA-SAC, Alltech Biotechnology Center, Nicholasville, $\mathrm{KY}$ ) increased FCM yields compared with control for the greater concentrate diet only (interaction: $P=0.06$ ) when evaluated at 2 different forage:concentrate ratios (50:50 and 40:60). The experiment was conducted with 2 different forage sources: grass hay and ammoniated wheat straw. Although the yeast treatment increased FCM for the $60 \%$ concentrate diet for both forages, the increase was because of opposite effects on yields of milk and milk fat for each forage treatment. Although the authors attributed the increase in FCM yield to a greater DMI for cows supplemented with the yeast, the mechanism by which yeast supplementation increased FCM was dependent upon forage source, which likely affected digestion kinetics in the rumen (not measured).

The reduction in DMI by HMC compared with DC is consistent with reduction of feed intake with increased starch fermentability and ruminal propionate production (Allen, 2000; Allen et al., 2005). Oba and Allen (2003) reported that HMC decreased DMI compared with DC in a $32 \%$ starch diet because of a reduction in meal size, despite an increase in meal frequency. The reduction in DMI by HMC compared with DC in the current experiment was because of decreased meal frequency despite a numerical increase in meal size. The reason for the different feeding behavior response causing the reduction in feed intake between the current experiment and that reported by Oba and Allen (2003) is not known. However, cows in the current experiment were slightly later in lactation (96 vs. 55 DIM at initiation of treatments) and had greater milk yield (43.5 vs. $38.6 \mathrm{~kg} / \mathrm{d}$ ), and differences in the source of corn affecting digestion kinetics and rate of propionate production might have had an effect.

Yields of milk protein, lactose, and SNF were not affected by treatment, so reductions in concentrations of milk protein and SNF for HMC compared with DC were likely because of increased milk yield. We were not able to determine the mechanism for the interaction of treatments on yield of milk fat in this experiment. Specific FA that are intermediates in biohydrogenation of dietary polyunsaturated FA cause milk fat depression by downregulation of expression of genes for key lipogenic enzymes (Harvatine and Bauman, 2006). These specific FA are only produced during altered ruminal fermentation (Bauman and Griinari, 2003). The first FA to be recognized was trans-10, cis-12 CLA (Baumgard et al., 2000), followed more recently by trans-9, cis-11 CLA and cis-10, trans-12 CLA (Bauman et al., 2008). No main effects or interactions of treatments were detected for concentration of trans-10, cis-12 CLA. Trans-9, cis-11 CLA and cis-10, trans-12 CLA were not detected with our methods. Although we cannot explain treatment effects by CLA, we cannot rule out that specific FA produced from altered ruminal fermentation inhibited milk fat production in this experiment, because other inhibitory FA may be discovered in the future.

Lack of effect of $\mathrm{YC}$ on ruminal $\mathrm{pH}$ is consistent with most previous reports with lactating dairy cows (Wiedmeier et al., 1987; Erasmus et al., 1992; Yoon and Stern, 1996). However, diet fermentability was more moderate for previous experiments with dairy cows, especially compared with our fermentable starch challenge. In an experiment with steers, YC limited the reduction in ruminal $\mathrm{pH}$ after a challenge with barley (Williams et al., 1991). In that study, ruminal lactate concentration peaked at approximately $8 \mathrm{~m} M$, which 
likely contributed to the decline in ruminal $\mathrm{pH}$. We failed to detect effects of $\mathrm{YC}$ on any measure of ruminal $\mathrm{pH}$. It is possible that high buffering capacity of the rumen combined with low lactate concentrations limited our ability to detect effect of YC. The large expected increase in fermentation acid production by HMC compared with DC had little effect on ruminal $\mathrm{pH}(\leq 0.14 \mathrm{pH}$ units $)$ despite the high-starch $(>32 \%)$ and low-NDF $(<26 \%)$ diets indicating high buffering capacity of rumen contents. Lactate is more effective at decreasing ruminal $\mathrm{pH}$ than the VFA, because it has a lower acid dissociation constant and is not readily absorbed from the rumen. Even if YC stimulated lactateutilizing bacteria as shown by Callaway and Martin (1997), low lactate concentrations limited effects of YC on ruminal $\mathrm{pH}$. We conclude that $\mathrm{YC}$ effect on milk fat yield was not related to its effect on ruminal $\mathrm{pH}$.

Effects of HMC compared with DC on ruminal VFA concentrations were consistent with increased production of fermentation acids. Relative production of propionate and butyrate compared with acetate was likely greater than reflected by the measured concentrations, because rate of absorption of VFA increases with chain length as pH declines (Dijkstra et al., 1993). Lack of main effects or interactions for $\mathrm{YC}$ on concentrations of total and individual VFA were consistent with most in vivo studies reported in the literature (Yoon and Stern, 1996; Putnam et al., 1997; Robinson and Garrett, 1999). Although concentrations of VFA in rumen fluid do not necessarily reflect production rates because of differences in absorption rates among VFA, it is unlikely that VFA caused the interaction of $\mathrm{YC}$ and starch fermentability on yield of milk fat in our experiment. Studies that have reported effects of YC on VFA concentrations reported increased propionate and decreased acetate concentrations in vivo (Harrison et al., 1988) and increased propionate production in continuous culture (Miller-Webster et al., 2002). This is inconsistent with YC effects on yield of milk fat observed in this experiment, because increased propionate and decreased acetate production should both decrease milk fat yield according to other theories of milk fat depression. Increased propionate production and subsequent increases in gluconeogenesis might decrease circulating plasma FA available for uptake by the mammary gland through actions of insulin (McClymont and Vallance, 1962), and decreased acetate supply might limit substrate for milk fat synthesis (Van Soest, 1963).

The reduction in frequency of ruminating bouts and weak tendency for reduction in ruminating chews and ruminating time per day by $\mathrm{YC}$ is a novel finding to our knowledge. Reduction in rumination with no effect on ruminal $\mathrm{pH}$ by $\mathrm{YC}$ further indicates that buffer capacity of rumen contents was relatively high, because flow of salivary buffers in saliva was likely decreased (Allen, 1997). We are unable to ascertain the mechanism for the reduction in rumination. It is unlikely that ruminating behavior was altered by osmotic effects, because total ruminal VFA concentrations, and likely osmolality (not measured), were similar for YC and CONT. It is possible that $\mathrm{YC}$ decreased rumination by increasing ruminal NDF digestion, thereby decreasing ruminal distension (not measured); YC has been reported to stimulate growth of cellulolytic bacteria in vivo with increased ruminal fiber digestibility (Wiedmeier et al., 1987). Alternatively, YC might contain a bioactive component that affected rumination. Effects of $\mathrm{YC}$ on ruminating behavior should be investigated further.

\section{CONCLUSIONS}

Yeast culture supplementation in diets of lactating dairy cows may decrease the incidence of milk fat depression commonly observed when ruminal starch fermentability is rapidly increased. Further research to elucidate the mechanisms involved is required to better understand the benefits of feeding $\mathrm{YC}$ in the diets of lactating dairy cows.

\section{ACKNOWLEDGMENTS}

We wish to acknowledge Diamond V Mills (Cedar Rapids, IA) for partial financial support of this research. We also thank R. A. Kreft, D. G. Main, B. J. Bradford, J. A. Voelker Linton, and J. S. Liesman (all in the Department of Animal Science, Michigan State University) for their technical assistance; the staff of the Michigan State University Dairy Cattle Teaching and Research Center for their assistance in this experiment; and West Central Soy (Ralston, IA) for donation of SoyPlus.

\section{REFERENCES}

Allen, M. S. 1997. Relationship between fermentation acid production in the rumen and the requirement for physically effective fiber. J. Dairy Sci. 80:1447-1462.

Allen, M. S. 2000. Effects of diet on short-term regulation of feed intake by lactating dairy cattle. J. Dairy Sci. 83:1598-1624.

Allen, M. S., B. J. Bradford, and K. J. Harvatine. 2005. The cow as a model to study food intake regulation. Annu. Rev. Nutr. 25:523-547.

AOAC. 1990. Official Methods of Analysis. Vol. 2. 15th ed. AOAC Int., Arlington, VA.

Bauman, D. E., and J. M. Griinari. 2003. Nutritional regulation of milk fat synthesis. Annu. Rev. Nutr. 23:203-227.

Bauman, D. E., J. W. Perfield, K. J. Harvatine, and L. H. Baumgard. 2008. Regulation of fat synthesis by conjugated linoleic acid: Lactation and the ruminant model. J. Nutr. 138:403-409.

Baumgard, L. H., B. A. Corl, D. A. Dwyer, A. Saebo, and D. E. Bauman. 2000. Identification of the conjugated linoleic acid isomer that inhibits milk fat synthesis. Am. J. Physiol. Regul. Integr. Comp. Physiol. 278:R179-R184. 
Bradford, B. J., and M. S. Allen. 2004. Milk fat response to a change in diet fermentability vary by production level in dairy cattle. J. Dairy Sci. 87:3800-3807.

Broderick, G. A., and J. H. Kang. 1980. Automated simultaneous determination of ammonia and total amino acids in rumen fluid and in vitro media. J. Dairy Sci. 63:64-75.

Callaway, E. S., and S. A. Martin. 1997. Effects of a Saccharomyces cerevisiae culture on ruminal bacteria that utilize lactate and digest cellulose. J. Dairy Sci. 80:2035-2044.

Chouinard, P. Y., L. Corneau, D. M. Barbano, L. E. Metzger, and D. E. Bauman. 1999. Conjugated linoleic acids alter milk FA composition and inhibit milk fat secretion in dairy cows. J. Nutr. 129:1579-1584.

Christie, W. W. 1982. A simple procedure for rapid transmethylation of glycerolipids and cholesteryl esters. J. Lipid Res. 23:10721075 .

Dado, R. G., and M. S. Allen. 1993. Continuous computer acquisition of feed and water intakes, chewing, reticular motility and ruminal pH of cattle. J. Dairy Sci. 76:1589-1600.

Dijkstra, J., H. Boer, J. Van Bruchem, M. Bruining, and S. Tamminga. 1993. Absorption of volatile fatty acids from the rumen of lactating dairy cows as influenced by volatile fatty acid concentration, $\mathrm{pH}$ and rumen liquid volume. Br. J. Nutr. 69:385-396.

Erasmus, L. J., P. M. Botha, and A. Kistner. 1992. Effect of yeast culture supplement on production, rumen fermentation and duodenal nitrogen flow in dairy cows. J. Dairy Sci. 75:30563065.

Hach, C. C., B. K. Bowden, A. B. Lopelove, and S. V. Brayton. 1987. More powerful peroxide Kjeldahl digestion method. J. Assoc. Off. Anal. Chem. 70:783-787.

Hara, A., and N. S. Radin. 1978. Lipid extraction of tissues with a low-toxicity solvent. Anal. Biochem. 90:420-426.

Harrison, G. A., R. W. Hemken, K. A. Dawson, R. J. Harmon, and K. B. Barker. 1988. Influence of addition of yeast culture supplement to diets of lactating cows on ruminal fermentation and microbial populations. J. Dairy Sci. 71:2967-2975.

Harvatine, K. J., and D. E. Bauman. 2006. SREBP1 and thyroid hormone responsive spot 14 (S14) are involved in the regulation of bovine mammary lipid synthesis during diet-induced milk fat depression and treatment with CLA. J. Nutr. 136:2468-2474.

Hoover, W. H. 1986. Chemical factors involved in ruminal fiber digestion. J. Dairy Sci. 69:2755-2766.

Karkalas, J. 1985. An improved enzymatic method for the determination of native and modified starch. J. Sci. Food Agric. 36:1019-1027.

Kramer, J. K., V. Fellner, M. E. Dugan, F. D. Sauer, M. M. Mossoba, and M. P. Yurawecz. 1997. Evaluating acid and base catalysts in the methylation of milk and rumen fatty acids with special emphasis on conjugated dienes and total trans fatty acids. Lipids 32:1219-1228.

McClymont, G. L., and S. Vallance. 1962. Depression of blood glycerides and milk-fat synthesis by glucose infusion. Proc. Nutr. Soc. 21:xli-xlii.
Miller-Webster, T., W. H. Hoover, M. Holt, and J. E. Nocek. 2002. Influence of yeast culture on ruminal microbial metabolism in continuous culture. J. Dairy Sci. 85:2009-2014.

NRC. 2001. Nutrient Requirements of Dairy Cattle. 7th rev. ed. Natl. Acad. Sci., Washington, DC.

Oba, M., and M. S. Allen. 2000. Effects of brown midrib 3 mutation in corn silage on productivity of dairy cows fed two concentrations of dietary neutral detergent fiber: 1 . Feeding behavior and nutrient utilization. J. Dairy Sci. 83:1333-1341.

Oba, M., and M. S. Allen. 2003. Effects of corn grain conservation method on feeding behavior and productivity of lactating dairy cows at two dietary starch concentrations. J. Dairy Sci. 86:174183

Piva, G., S. Belladonna, G. Fusconi, and F. Sicbaldi. 1993. Effects of yeast on dairy cow performance, ruminal fermentation, blood components, and milk manufacturing properties. J. Dairy Sci. $76: 2717-2722$.

Putnam, D. E., C. G. Schwab, M. T. Socha, N. L. Whitehouse, N. A. Kierstead, and B. D. Garthwaite. 1997. Effect of yeast culture in the diets of early lactation dairy cows on ruminal fermentation and passage of nitrogen fractions and amino acids to the small intestine. J. Dairy Sci. 80:374-384.

Robinson, P. H., and J. E. Garrett. 1999. Effect of yeast culture (Saccharomyces cerevisiae) on adaptation of cows to postpartum diets and on lactational performance. J. Anim. Sci. 77:988-999.

Stone, W. C. 2004. Nutritional approaches to minimize subacute ruminal acidosis and laminitis in dairy cattle. J. Dairy Sci. 87(E Suppl.):E13-E26.

Van Soest, P. J. 1963. Ruminant fat metabolism with particular reference to factors affecting low milk fat and feed efficiency. A review. J. Dairy Sci. 46:206-216.

Van Soest, P. J., J. B. Robertson, and B. A. Lewis. 1991. Methods for dietary fiber, neutral detergent fiber and nonstarch polysaccharides in relation to animal nutrition. J. Dairy Sci. 74:3583-3597.

Wang, Z., M. L. Eastridge, and X. Qiu. 2001. Effects of forage neutral detergent fiber and yeast culture on performance of cows during early lactation. J. Dairy Sci. 84:204-212

Wiedmeier, R. D., M. J. Arambel, and J. L. Walters. 1987. Effect of yeast culture and Aspergillus oryzae fermentation extract on ruminal characteristics and nutrient digestibility. J. Dairy Sci 70:2063-2068.

Wildman, E. E., G. M. Jones, P. E. Wagner, R. L. Boman, H. F. Troutt Jr., and T. N. Lesch. 1982. A dairy cow body condition scoring system and its relationship to selected production characteristics. J. Dairy Sci. 65:495-501.

Williams, P. E., C. A. Tait, G. M. Innes, and C. J. Newbold. 1991. Effects of the inclusion of yeast culture (Saccharomyces cerevisiae plus growth medium) in the diet of dairy cows on milk yield and forage degradation and fermentation patterns in the rumen of steers. J. Anim. Sci. 69:3016-3026.

Yoon, I. K., and M. D. Stern. 1996. Effects of Saccharomyces cerevisiae and Aspergillus oryzae cultures on ruminal fermentation in dairy cows. J. Dairy Sci. 79:411-417. 